\title{
Осаждение аморфных и микрокристаллических пленок кремния газоструйным плазмохимическим методом
}

\author{
(C) В.Г. Щукин, В.О. Константинов , Р.Г. Шарафутдинов \\ Институт теплофизики им. С.С. Кутателадзе Сибирского отделения Российской академии наук, \\ 630090 Новосибирск, Россия \\ ฯ E-mail: konstantinov@itp.nsc.ru
}

Поступила в Редакцию 21 января 2019 г.

В окончательной редакции 24 июня 2019 г.

Принята к публикации 26 июля 2019 г.

Газоструйным плазмохимическим методом с активацией газа электронным пучком получены равномерные тонкие пленки аморфного и микрокристаллического кремния в форвакуумном диапазоне давлений. Исследовано влияние расхода газа-носителя аргона, концентрации моносилана, давления в реакционной камере, материала подложки и величины тока активирующего электронного пучка на скорость осаждения, фоточувствительность и кристалличность слоев кремния. Для пленок аморфного кремния достигнуты скорости осаждения $>1 \mathrm{Hм} / \mathrm{c}$, а для слоев с кристалличностью, превышающей $60 \%$, скорость осаждения превысила 0.6 нм/с. Установлено, что материал подложки не влияет на структуру осаждаемых слоев кремния и скорость их осаждения.

Ключевые слова: плазмохимическое осаждение, газовые струи, тонкие пленки, аморфный и микрокристаллический кремний.

DOI: 10.21883/FTP.2019.12.48634.9068

\section{1. Введение}

Новые методы, позволяющие с высокими скоростями при низкой температуре осаждать пленки аморфного и микрокристаллического кремния, вызывают повышенный интерес исследователей. Это связано с тем, что существующие промышленные методы создания тонкопленочных солнечных элементов (СЭ) практически исчерпали свой ресурс по увеличению производительности, типичные скорости осаждения кремниевых пленок составляют десятые доли нм/с [1]. Помимо этого низкие температуры осаждения позволяют использовать в качестве подложки пластик, что очень важно при производстве легких и гибких СЭ [2-4]. Аморфный кремний с точки зрения создания на его основе СЭ обладает рядом положительных характеристик, наиболее значимой из которых является сильное поглощение света в видимой области. Это позволяет создавать на его основе приборы с высокой фоточувствительностью, но имеющие толщину < 1 мкм [5]. Основным недостатком СЭ на базе аморфного кремния является деградация его характеристик при выдерживании на свету [6]. Одним из приемов борьбы с этим эффектом является создание двухпереходных СЭ, где одновременно с уменьшением толщины ячейки на основе аморфного кремния создается еще одна ячейка на основе микрокристаллического кремния, практически лишенная световой деградации [7]. Однако микрокристаллический кремний (mc-Si:H), являясь непрямозонным полупроводником, для достаточного поглощения должен иметь толщину в несколько мкм, что предъявляет высокие требования к скорости его осаждения в структуре СЭ. Наиболее распространенным способом получения mc-Si:H является снижение концентрации моносилана в газе-разбавителе аргоне или водороде $[8,9]$ относительно условий осаждения пленок аморфного кремния, что приводит к еще большему уменьшению и так невысокой скорости его осаждения. Наиболее предпочтительными с точки зрения применения в тонкопленочных СЭ являются слои кремния с кристалличностью $>40 \%[10,11]$.

Целью работы являлось исследование скоростей осаждения, кристаллической структуры и фоточувствительности тонких пленок кремния, полученных газоструйным плазмохимическим методом [12] с использованием плазмотрона новой модификации [13].

\section{2. Экспериментальная установка и методика}

Эксперименты проводились на газодинамической установке низкой плотности Института теплофизики СО РАН. Схема экспериментальной установки приведена на рис. 1.

В качестве генератора плазмы использовался холодный плазмотрон, состоящий из электронной пушки 1 с полым катодом, с помощью которой формировался пучок электронов 2, и соплового блока 3 , представляющего собой систему кольцевых сопел Лаваля. Сопловой блок применялся для подачи смеси аргона с кремнийсодержащим газом (моносилан, $\mathrm{SiH}_{4}$ ) в реакционную вакуумную камеру 4 в виде сверхзвуковой струи 5 , а также как газовый затвор [14]. Минимизированный при помощи газового затвора обратный поток газа отводили через секцию промежуточной откачки 6. При взаимодействии молекул струи газа с электронным пучком 


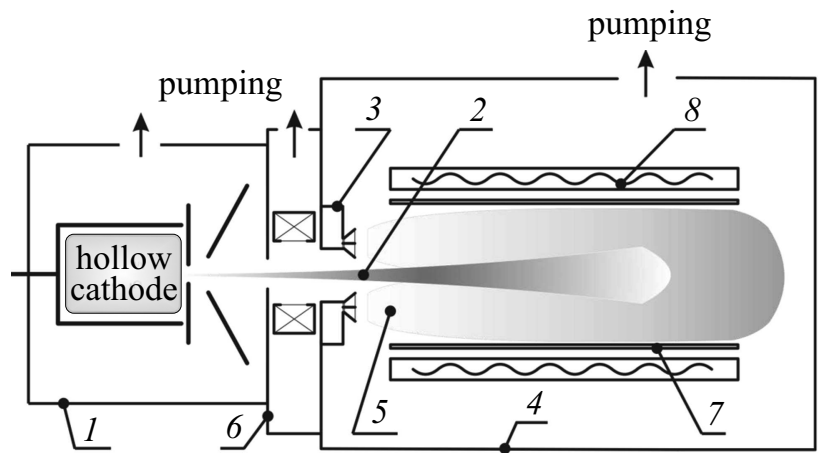

Рис. 1. Схема экспериментальной установки: 1 - электронная пушка с полым катодом, 2 - электронный пучок, 3 - сопловой блок, 4 - реакционная вакуумная камера, 5 - сверхзвуковая струя газа, $6-$ секция промежуточной откачки, 7 - подложка, 8 - нагреватель.

образовывалась низкотемпературная электронно-пучковая плазма высокой плотности, содержащая химически активные частицы. Частицы, достигнув подложек 7, размещенных на нагревателе 8 , формировали пленку кремния.

В данной работе представлены результаты экспериментов по осаждению тонких пленок кремния. Для нахождения оптимальных значений кристалличности и проводимости пленок кремния параметры газоструйного плазмохимического метода осаждения изменялись в следующих диапазонах: ток пучка электронов от 50 до $200 \mathrm{MA}$, расход аргона от 4 до $12 \mathrm{slm}$ ( $\mathrm{slm}$ - нормальный литр в минуту, т.е. литр газа при нормальных условиях - температуре $273 \mathrm{~K}$, давлении 101325 Па). Также исследовалось влияние типа подложки на характеристики осаждаемых пленок кремния. Давление в вакуумной камере в зависимости от расхода аргона поддерживалось на уровне от 4 до 14 Па. Энергия первичного пучка электронов и расход моносилана были постоянными и составляли 1 кэВ и $0.2 \mathrm{slm}$ соответственно.

Кристалличность осажденных слоев кремния определялась с помощью обработки спектров комбинационного рассеяния света (КРС). Для работы использовался спектрометр с тройным монохроматором Т64000 производства компании Horiba Jobin Yvon. Для получения данных о кристалличности спектр КРС раскладывали на три гауссовых пика [15]. Значения темновой проводимости и фотопроводимости определяли четырехзондовым методом при помощи вольтметра-электрометра В7-30 на подложках из монокристаллического кремния с термическим окислом $\mathrm{SiO}_{2}$, имеющим толщину 100 нм. После осаждения слоев кремния на его поверхность в вакууме напылялась контактная никелевая сетка. Для получения данных о фотопроводимости образец облучался лампой, близкой по характеристикам к источнику света АМ 1.5. Толщины пленок измерялись на сканирующем эллипсометре ЛЭФ-81 „Микроскан“ и по спектрам отражения в ближней инфракрасной обла- сти (800-2000 нм) на спектрофотометре UV-3101 РС Shimadzu.

\section{3. Результаты эксперимента и обсуждение}

Как уже отмечалось выше [12], ранее нами были получены тонкие пленки аморфного и микрокристаллического кремния, имеющие приборное качество. В данной работе для получения таких пленок мы использовали новый тип плазматрона, основным отличием которого от предыдущей модификации является более высокая электронно-пучковая мощность, возможность изменять угол расфокусировки электронного пучка, а также способность работы в более высоком диапазоне давлений, вплоть до форвакуумного режима. Варьируемые параметры экспериментов приведены в таблице. Энергия первичного пучка электронов и расход моносилана были постоянными и составляли 1 кэВ и $0.2 \mathrm{slm}$ соответственно для всех экспериментов.

На рис. 2 приведены зависимости скорости осаждения от давления в реакционной камере, полученные при различных значениях расхода аргона в режимах I, II, III из таблицы. Видно, что при увеличении давления в реакционной камере вплоть до форвакуумного скорость осаждения пленок кремния возрастает при всех значениях расхода аргона. При этом с увеличением расхода аргона скорость осаждения уменьшается.

Такое поведение зависимости скорости осаждения при увеличении давления можно объяснить увеличением плотности газовой струи, на которой происходит рассеяние первичного пучка электронов, приводящее к росту числа активированных молекул моносилана, из которых растет пленка. Меньшая скорость осаждения при большем расходе аргона, по-видимому, связана с

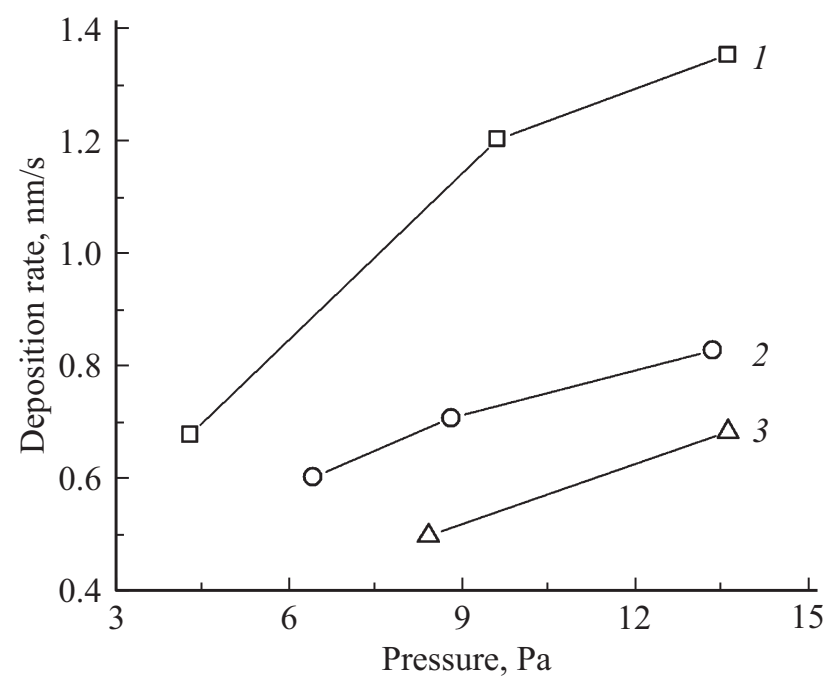

Рис. 2. Зависимость скорости осаждения от давления. $G(\operatorname{Ar})=4(1), 8(2)$ и $12 \operatorname{sim}(3)$. 
Условия экспериментов

\begin{tabular}{c|c|c|c|c}
\hline Режим & $I($ beam $)$, мА & $P$, Па & $G(\mathrm{Ar}), \mathrm{slm}$ & Подложка \\
\hline I & 100 & От 4.3 до 13.6 & 4 & Нерж. сталь \\
II & 100 & От 6.4 до 13.3 & 8 & Нерж. сталь \\
III & 100 & От 8.4 до 13.6 & 12 & Нерж. сталь \\
IV & От 75 до 175 & 4.3 & 4 & Нерж. сталь \\
V & 100 & 4.4 & 4 & Пластина Si \\
VI & 75 & 8.1 & 12 & Пластина Si \\
VII & 75 & 7.9 & 12 & Нерж. сталь
\end{tabular}

Примечание. I (beam) - ток первичного пучка электронов, $G-$ расход газа, $P$ - фоновое давление в реакционной камере. „Нерж. сталь“ - нержавеющая сталь.

уменьшением концентрации кремнийсодержащей компоненты в газовом потоке, что приводит к меньшей доле активированных частиц. Иными словами, с увеличением расхода аргона при сохранении расхода кремнийсодержащего газа рассеяние первичного пучка электронов происходит в большей степени на молекулах аргона. Такое поведение скорости осаждения при изменении концентрации моносилана и давления отмечено у многих авторов [8,16-19].

На рис. 3 представлена зависимость скорости осаждения от тока пучка электронов, полученная в режиме IV из таблицы. Как видно из рисунка, при увеличении тока пучка электронов скорость осаждения линейно растет. Это, как было показано ранее [20], можно объяснить увеличением количества активированных молекул моносилана. При этом линейный вид зависимости от тока говорит о том, что активация происходит прямым электронным ударом [21,22]. При этом скорость осаждения может быть увеличена вплоть до $2 \mathrm{Hм} / \mathrm{c}$ за счет повышения тока до значений 300 мА [13].

На рис. 4 приведены спектры КРС образцов, полученных в режимах V и VI из таблицы. Видно, что при расходе аргона $4 \mathrm{slm}$ получаются пленки аморфного кремния, в то время как при $12 \mathrm{slm}$ происходит осаждение пленки микрокристаллического кремния с кристалличностью на уровне $60 \%$, т.е. при увеличении расхода аргона происходит кристаллизация получаемого материала. Это объясняется уменьшением скорости осаждения за счет снижения концентрации моносилана в газовой смеси [5], дающим возможность частицам, формирующим пленку, занять более энергетически выгодное положение в ее структуре. Еще одним фактором, способствующим образованию кристаллической фазы, является ионная бомбардировка поверхности растущей пленки ионами аргона, что эквивалентно увеличению температуры осаждения и способствует увеличению поверхностной диффузии, необходимой для роста микрокристаллического кремния [23].

На рис. 5 приведены зависимости степени кристалличности от продольной координаты $x$ для различных типов подложек, полученные в режимах VI и VII из таблицы. Видно, что степень кристалличности не зависит от типа

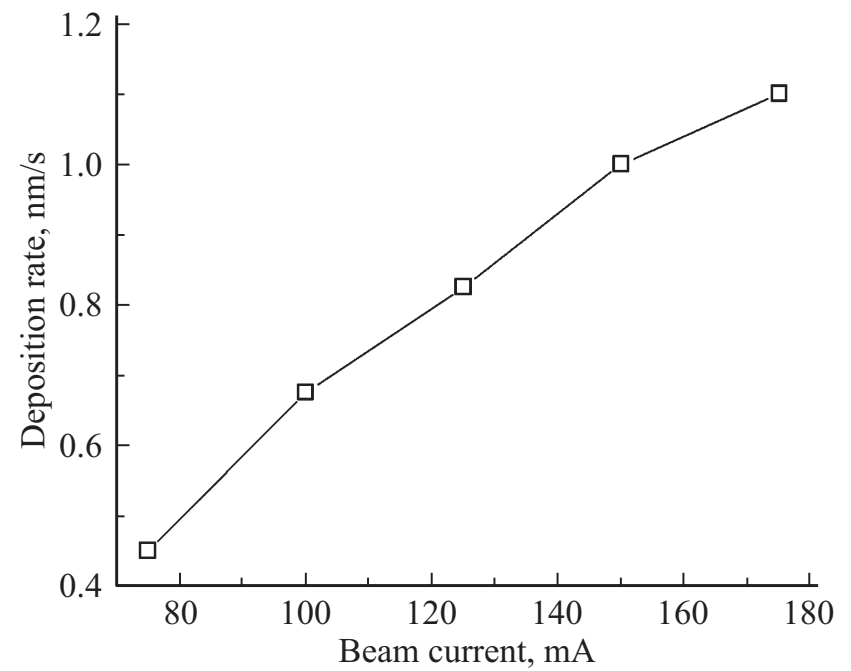

Рис. 3. Зависимость скорости осаждения от тока пучка.

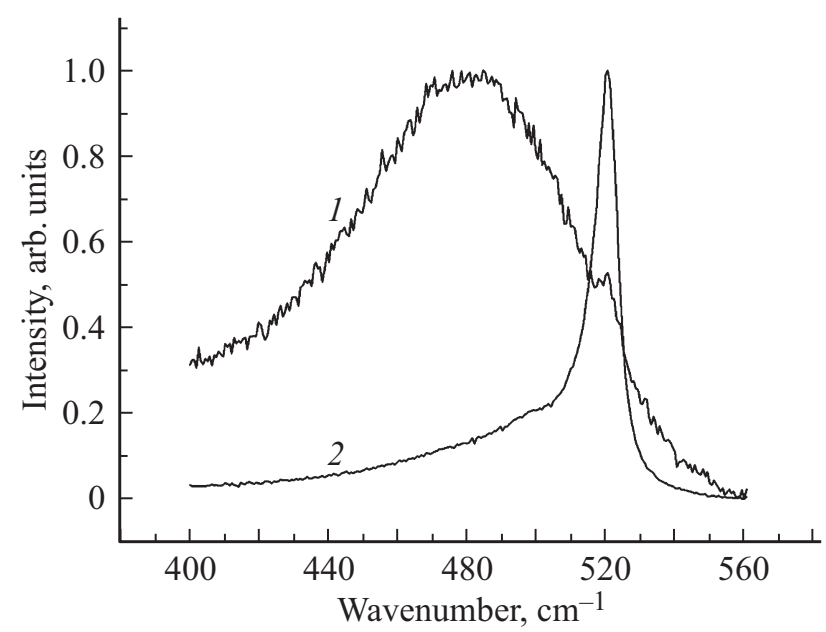

Рис. 4. Спектры комбинационного рассеяния света: 1 - пленка аморфного кремния, 2 - пленка микрокристаллического кремния.

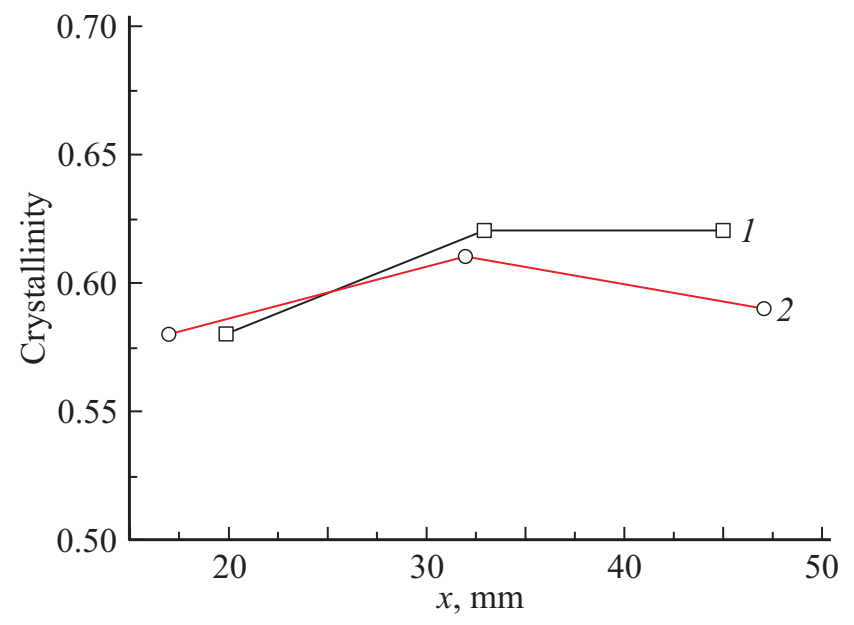

Рис. 5. Влияние материала подложки на продольный профиль кристалличности кремниевого слоя: 1 - пластина $\mathrm{Si}$, 2 - нержавеющая сталь. 


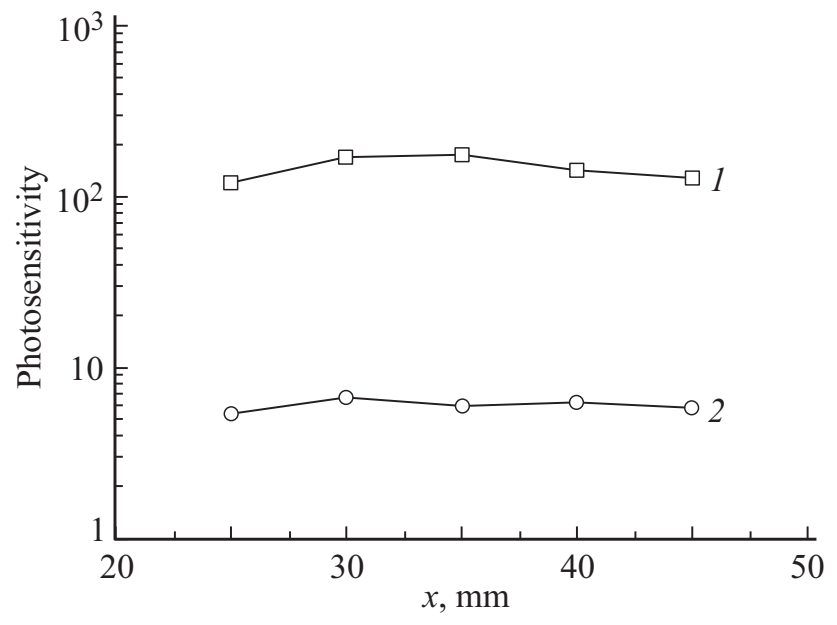

Рис. 6. Влияние структуры получаемого материала на продольный профиль фоточувствительности: 1 - аморфный кремний, 2 - микрокристаллический кремний.

поверхности, на которую происходит осаждение, при этом неравномерность кристалличности на осаждаемых пленках составляет не более $7 \%$.

На рис. 6 представлены зависимости фоточувствительности от продольной координаты для различного материала, полученного в режимах V и VI из таблицы. Видно, что газоструйным плазмохимическим методом получены равномерные фоточувствительные слои как аморфного, так и микрокристаллического кремния, пригодные для создания на их основе тонкопленочных солнечных элементов.

\section{4. Заключение}

В данной работе газоструйным плазмохимическим методом осаждены фоточувствительные слои аморфного и микрокристаллического кремния в форвакуумном диапазоне давлений с высокими скоростями осаждения. При этом полученные пленки обладают однородной по поверхности кристаллической структурой и равномерными оптоэлектронными характеристиками.

Установлено, что увеличение значений тока пучка электронов или давления в реакционной камере приводит к росту скорости осаждения пленок кремния, в то время как повышение расхода аргона влечет за собой падение скорости.

\section{Финансирование работы}

Работа выполнена при поддержке Российского фонда фундаментальных исследований и Министерства образования, науки и инновационной политики Новосибирской области, Конкурс проектов 2017 года фундаментальных научных исследований, проводимый РФФИ и субъектами Российской Федерации, 17-48-540665 p_a, a также Министерства образования и науки Российской
Федерации, Проект III.18.2.5: Фундаментальные теплофизические основы получения совершенных монокристаллов и пленок, Гос. рег. АААА-А17-117022850021-3, ГЗ 0322-2018-0005.

\section{Конфликт интересов}

Авторы заявляют, что у них нет конфликта интересов.

\section{Список литературы}

[1] A. Terakawa. Sol. Energy Mater. Sol. Cells, 119, 204 (2013).

[2] M. Tanda, K. Tabuchi, M. Uno, S. Kato, Y. Takeda, S. Iwasaki, Y. Yokohama, T. Wada, M. Shimosawa, Y. Sakakibara, A. Takano, H. Nishihara, H. Enomoto, T. Kamoshita. Proc. 31st IEEE PVSC (Lake Buona Vista, USA, 2005) p. 1560.

[3] F.-J. Haug, T. Söderström, M. Python, V. Terrazzoni-Daudrix, X. Niquille, C. Ballif. Sol. Energy Mater. Sol. Cells, 93, 884 (2009).

[4] P. Alpuim, G.M. Junior, S.A. Filonovich, P. Roca i Cabarrocas, J.-E. Bouree, E.V. Johnson, Y.M. Soro. Proc. 23rd EU PVSEC (Valencia, Spain, 2008) p. 2455.

[5] A.V. Shah, J. Meier, E. Vallat-Sauvain, N. Wyrsch, U. Kroll, C. Droz, U. Graf. Sol. Energy Mater. Sol. Cells, 78, 469 (2003).

[6] D.L. Staebler, C.R. Wronski. Appl. Phys. Lett., 31, 292 (1977).

[7] J. Meier, S. Dubail, R. Fluckiger, D. Fischer, H. Keppner, A. Shah. Proc. 1st IEEE World Conf. on Photovoltaic Energy Conversion (Waikoloa, USA, 1994) p. 409.

[8] T. Kamei, P. Stradins, A. Matsuda. Appl. Phys. Lett., 74 (12), 1707 (1999).

[9] S. Guha, J. Yang, B. Yan. Sol. Energy Mater. Sol. Cells, 119, 1 (2013).

[10] S. Guha. Phys. Status Solidi A, 207, 671 (2010).

[11] S. Mukhopadhyay, R. Goswami, S. Ray. Sol. Energy Mater. Sol. Cells, 93, 674 (2009).

[12] R.G. Sharafutdinov, S.Ya. Khmel, V.G. Shchukin, M.V. Ponomarev, E.A. Baranov, A.V. Volkov, O.I. Semenova, L.I. Fedina, P.P. Dobrovolsky, B.A. Kolesov. Sol. Energy Mater. Solar Cells, 89, 99 (2005).

[13] В.Г. Щукин, В.О. Константинов, В.С. Морозов. ЖТФ, 6, 914 (2018).

[14] Р.Г. Шарафутдинов, П.А. Сковородко, С.А. Городецкий, В.М. Карстен, В.О. Константинов, В.Г. Щукин. Пат. 2612267 РФ, МПК В01J19/08, С23C14/00, С23C16/513, C23C16/54, С23C26/00, Н01J37/32. Опубл. 03.03.2017. Бюл. № 7.

[15] D. Das, M. Jana, A.K. Barua, S. Chattopadhyay, L.C. Chen, K.H. Chen. Jpn. J. Appl. Phys., 41, 229 (2002).

[16] B. Rech, T. Roschek, J. Muller, S. Wieder, H. Wagner. Sol. Energy Mater. Sol. Cells, 66, 267 (2001).

[17] P. Roca i Cabarrocas. Curr. Opin. Solid State Mater. Sci., 6, 439 (2002).

[18] Y. Mai, S. Klein, R. Carius, J. Wolff, A. Lambertz, F. Finger. J. Appl. Phys., 97, 114913 (2005).

[19] T. Matsui, M. Kondo. Sol. Energy Mater. Sol. Cells, 119, 156 (2013).

[20] В.О. Константинов, В.Г. Щукин, Р.Г. Шарафутдинов, В.М. Карстен, Г.Г. Гартвич, О.И. Семенова. Прикл. физика, № 4, 95 (2009). 
[21] А.Е. Беликов, Н.В. Карелов, А.К. Ребров, Р.Г. Шарафутдинов. В сб.: Диагностика потоков разрежсенного газа, под ред. С.С. Кутателадзе, А.К. Реброва (Новосибирск, 1979) c. 7.

[22] Г. Месси. Электронные и ионные столкновения (М., Изд-во Иностр. лит., 1958).

[23] J.K. Rath. Sol. Energy Mater. Sol. Cells, 76, 431 (2003).

Редактор Л.В. Шаронова

\title{
Deposition of amorphous and microcrystalline silicon films by gas-jet plasma-chemical method
}

\author{
V.G. Shchukin, V.O. Konstantinov, R.G. Sharafutdinov
}

Kutateladze Institute of Thermophysics,

Siberian Branch of Russian Academy of Sciences, 630090 Novosibirsk, Russia

\begin{abstract}
Using gas-jet plasma-chemical method with gas activation by an electron beam, uniform thin films of amorphous and microcrystalline silicon in the forevacuum pressure range were obtained. Effects of argon carrier gas flow rate, monosilane gas concentration, background pressure in the reaction chamber, the substrate material, and the magnitude of the activating electron beam current on the deposition rate, photosensitivity, and crystallinity of silicon layers were studied. Deposition rate above $1 \mathrm{~nm} / \mathrm{s}$ was achieved for films of amorphous silicon, and for layers with crystallinity about $60 \%$ the deposition rate was exceeded $0.6 \mathrm{~nm} / \mathrm{s}$. It is established that the substrate material does not affect the structure of the deposited silicon layers and their deposition rate.
\end{abstract}

